\title{
The second case of cutaneous myiasis caused by Cordylobia anthropophaga (Tumbu fly) in Sri Lanka
}

T. de S. Naotunna', M. M. Ismail ${ }^{2}$ and R. L. Ihalamulla ${ }^{3}$

The Ceylon Journal of Medical Science 2000; 43: 31-33

\section{Summary}

A Sri Lankan man who had been to Cameroon in Africa and stayed there for 15 days had contracted myiasis caused by the larva of Cordylobia anthropophaga ('Tumbu fly'). Identification of the larva and its implications are discussed. This the second reported case of such an infection acquired abroad by a Sri Lankan.

\section{Introduction}

Invasion of living tissue by the larvae of certain species of the Order Diptera which comprises insects whose adults possess one pair of wings and a pair of halteres is called myiasis. The larvae of certain species of flies belonging to the genera Dermatobia, Callitroga, Chrysomyia and Cordylobia of the above Order have been responsible for causing myiasis in the tropics. Cordylobia anthropophaga (Blanchard) which is commonly referred to in Africa (where it is restricted to) as the "Tumbu fly" or the "Mango fly" or the "Skin maggot fly" is a non-metallic calliphorine with a vast area of distribution within the continent from Senegal and Ethiopia up in the North to Natal down in the South (1).

To date, there have been only five cases of human myiasis reported from Sri Lanka. Three of these due to Chrysomyia bezziana were indigenously acquired and the fourth due to C. anthropophaga was acquired following a visit to Africa. The first report is about two cases of myiasis of the nose and the ears due to $C$. bezziana secondary to chronic suppurative sinusitis and chronic otitis media respectively (2). The third case of wound myiasis due to C. bezziana has been reported from a chronic ulcer in the right foot of a 70 year old female (3). A case of myiasis on the scalp of a 10 month old infant who had previously been in Zimbabwe with his Sri Lankan parents has been attributed to C. anthropophaga which is not found in Sri Lanka (4). The $5^{\text {th }}$ case is that of a 28 year old German national who had acquired myiasis of the scalp due to the larvae of Dermatobia hominis while on tour in Sri Lanka (5).

\section{Case Report}

Here we describe the second imported case of cutaneous myiasis due to C. anthropophaga in a Sri Lankan adult male following a 2-week visit to Cameroon, Africa. The patient is a 46 year old factory mechanic who had gone to Cameroon to undergo a short course of training related to his work. Two days before leaving Cameroon he had noticed a slightly tender, reddish-pink papule about $6 \mathrm{~cm}$ below and $1.5 \mathrm{~cm}$ medial to the right acromioclavicular joint in the skin of his anterior chest (Fig. 1). During the first three days there had been a slight, localized pain but no itching or fever. Ten days after he had first noticed the lesion, a live whitish maggot had popped out on squeezing the lesion.

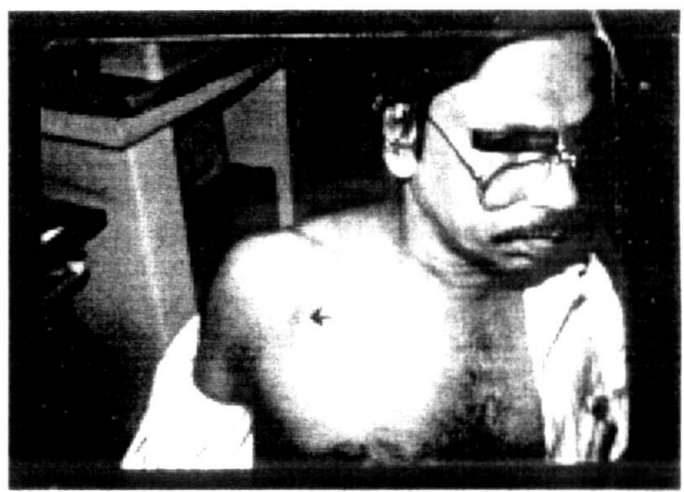

Fig. 1: Lesion (arrow) at the maggot's exit on the chest

1. 3/31, Hanover Street, Wardes Town, Wellington, New Zealand.

2. 159, Kynsey Road, Colombo 08, Sri Lanka.

3. Department of Parasitology, Faculty of Medicine, University of Colombo, Colombo 8, Sri Lanka. 


\section{Description of the larva}

The larva is a creamy white maggot (Fig. 2), measuring $13 \mathrm{~mm}$, in length and $7 \mathrm{~mm}$, in width having a sluggish movement. The body is broadly oval, cone shaped consisting of twelve clearly marked segments covered with backwardly directed curved spines.

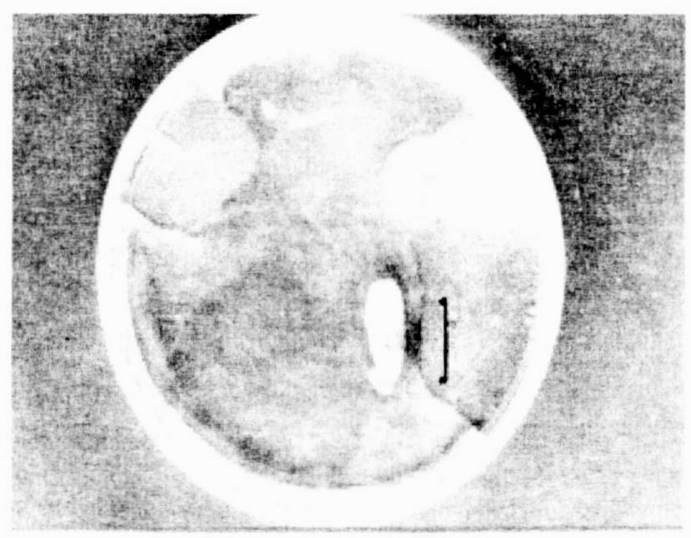

Fig. 2: Maggot ( $3^{\text {rd }}$ instar larva) of "Tumbu fly", Bar $=10 \mathrm{~mm}$

The cephaloskeleton was dissected and this and the posterior spiracles were mounted in Depex after standard fixing, dehydration and clearing procedures. The labial sclerites of the cephaloskeleton are long and curved (Fig. 3). The peritreme of the posterior spiracles is only faintly sclerotised and the slits slightly sinuous giving it a question mark (?) appearance while the button is indistinct. The larva was identified as a $3^{\text {rd }}$ instar larva of C. anthropophaga.

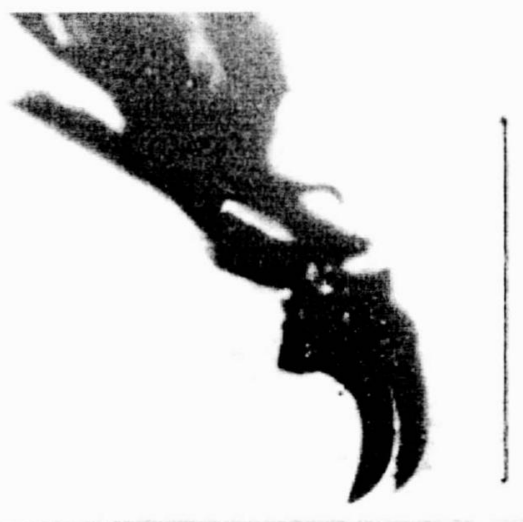

Fig. 3: Cephaloskeleton of the $3^{\text {rd }}$ instar larva of "Tumbu fly", Bar $=500 \mu \mathrm{m}$

\section{Discussion}

The labial sclerites of the cephaloskeleton of the maggot are long and curved which feature differentiates the $3^{\text {rd }}$ instar larva of $C$. anthropophaga from those of other species of the genus (6). The structure of the posterior spiracles with the indistinct peritreme and button and the somewhat sinuous slit is typical of the species.

The female fly lays eggs in urine or faeces contaminated with dry sand or soil and also on dirty linen or clothes when hung out to dry. The larva hatches out after one to three days and remains attached to the surface. On coming into contact with a host it penetrates the skin, enters the dermis and remains there until mature.

Cameroon where the patient had stayed is a country situated within the area inhabited by $C$. anthropophaga. He stated that when clothes were hung out to dry, swarms of flies were found resting on them. It is likely that he got the infection from these clothes.

Though many 1st instar larvae may enter and establish themselves in the skin of the host all do not undergo development to reach maturity, there being a vast difference between the number of larvae reaching maturity and the 1st instar larvae entering the skin. This may partly be due to the innate resistance of the host to the infection and might probably explain why even though the clothes hung out were teeming with flies only a single maggot was able to establish itself in the patient's skin. Some degree of immunity due to the previous infection is said to be acquired by humans as well as animals. In man this may not last longer than a year (6).

Penetration of the 1st instar larva hardly causes any irritation but in some cases significant skin reactions do occur. During the 1st two days a slight pricking pain may at times be experienced. The furuncle grows in size but the itching stops for a few days and recurs later with the pain interfering with sleep. Exudation of serous fluid may take place with the tissue round the boil becoming indurated and red in colour. 
In this case there was only one larva but if several larvae are present and if adults of both sexes are released from these, there is a chance for the fly to breed and multiply. Since there is a wide variety of indigenous potential hosts such as rodents and the climatic conditions are conducive for the fly, the possibility of the infection getting established in this country is a matter of concern especially because of increased travel between Africa and Sri Lanka today due to employment opportunities and tourism. Steps should be taken to monitor these imported infections as these could be potential health hazards.

\section{Acknowledgements}

We thank Dr.S.S. Jayaratne, Consultant Surgeon, National Hospital of Sri Lanka for providing us the case and Mrs. Himali Gunatilaka, Dept, of Parasitology, Faculty of Medicine, Colombo 08 for help in preparation of the manuscript and Mr. R. A .A. N. Ranawaka, Photographic Unit, Dept. of Pharmacology of the same Faculty.

\section{References}

1. Gordon RM, Lavoipierre MMJ. Entomology for Students of Medicine. London Blackwell Scientific Publications 1976; pp 195-196.

2. Bayer HGA. Myiasis maligna of nose and ears in Ceylon: recommendation of a new treatment. Archives of Otolaryngology 1954; 1: 104-107.

3. De Silva NR, Madagedera D, et al. Wound myiasis due to Chrysomya bezziana: a case report. Kandy Medical Journal 1992; 1: 75-76.

4. Edirisinghe JS, Rajapakse C. Myiasis due to Cordylobia anthropophaga, the "Tumbu fly" in a Sri Lankan infant. Ceylon Medical Journal 1991; 36: 112-115.

5. Jacobi CA, Bruns C, Keller HW. Myiasis of the scalp; an incidental finding in ambulatory surgery. Zentralblalt fur Chirgie 1994; 119: 733-735.

6. Zumpt F. Myiasis in man and animals in the Old World. London Butterworths 1965; pp 70-74. 